\title{
The Effect of Local Taxes, General Allocation Funds, and Special Allocation Funds on Capital Expenditures of the Government of South Sumatra Province 2010 - 2019
}

\author{
Ayunda D. Maharani ${ }^{1)}$, Harsi Romli ${ }^{2)}$, Vhika Meiriasari ${ }^{3)}$ \\ 1), 2), 3) Program Studi Akuntansi, Universitas Indo Global Mandiri, Palembang, Indonesia \\ Email:ayundadinamaharani@gmail.com ${ }^{1)}$,harsi_romli@uigm.ac.id²),vhikams@uigm.ac.id ${ }^{3)}$
}

\begin{abstract}
This study aims to examine the effect of local taxes, general allocation funds and special allocation funds on the capital expenditure of the South Sumatra Province government for the 2010-2019 period. The data used in this study are primary and secondary. Furthermore, the data were analyzed using multiple linear regression. This study prove that the general allocation funds have a positive effect on the capital expenditure of the South Sumatra provincial government. While, local taxes and special allocation funds are not proven to have a positive effect on the capital expenditure of the South Sumatra provincial government. Furthermore, the test results of the coefficient of determination $\left(\mathrm{R}^{2}\right)$ obtained a value of 0,773 . This shows that the amount of the contribution of the tax variables, general allocation funds and special allocation funds can explain the capital expenditure of $77,30 \%$ the remaining is influenced by other variables included in this study.
\end{abstract}

Keywords: local taxes, general allocation funds, special allocation funds, capital expenditures

\section{Introduction}

\subsection{Background}

The government's policy instrument, namely fiscal decentralization, has the principles and objectives to reduce the fiscal gap between the central and regional governments as stipulated by Law no. 33 of 2004 concerning Regional Governments in facing the development of conditions, both at home and abroad, as well as the challenges of global competition, it is deemed necessary to carry out Regional Autonomy by giving broad, real and proportional authority to the regions.

The implementation of regional autonomy will directly affect the system of financing, management, and supervision of regional finances. The regional financing system in the context of regional autonomy is one of the most important aspects. Regions are expected to increase their fiscal capacity in order to be able to meet fiscal needs so as not to experience a fiscal gap. One of the efforts to increase the capacity of these regions is to increase the value of Regional Taxes, General Allocation Funds, and Special Allocation Funds through Capital Expenditures.

Based on Law Number 16 of 2009 , tax is a mandatory contribution to the state owned by an individual or entity that is coercive under the law, without receiving direct reciprocity, and is used for the needs of the state for the greatest prosperity of the people. General allocation funds are funds sourced from APBN revenues which are then allocated with the aim of financial equity between regions to fund regional needs for the framework of implementing decentralization also aiming at equitable distribution and reducing financial capacity gaps between regions through the application of a formula that takes into account the needs and potential of the region (Darise, 2009). Based on Law Number 20 of 2019, Special Allocation 
Funds are funds sourced from APBN revenues to certain regions with the aim of helping to fund special activities which are regional affairs and in accordance with national priorities. Regulation of the Minister of Home Affairs Number 21 of 2010 article 53 explains that capital expenditure is expenditure used for expenditures made in the context of purchasing or procurement and construction of fixed assets and has a useful value of more than 12 months used in government activities such as land, machine tools, buildings. , buildings, roads, irrigation, and more.

Table 1. Development of Capital Expenditure Realization of South Sumatra Province

\begin{tabular}{|c|c|c|}
\hline Tahun & $\begin{array}{c}\text { Realisasi Belanja Modal Provinsi Sumatera } \\
\text { Selatan (Dalam Rupiah) }\end{array}$ & $\begin{array}{c}\text { Realisasi } \\
\text { Dari APBD (\%) }\end{array}$ \\
\hline 2010 & 1.032 .890 .015 .887 & $3.14 \%$ \\
\hline 2011 & 1.139 .120 .156 .279 & $3.47 \%$ \\
\hline 2012 & 1.017 .132 .902 .101 & $5.13 \%$ \\
\hline 2013 & 862.903 .668 .426 .4 & $6.33 \%$ \\
\hline 2014 & 733.382 .314 .935 .17 & $8.52 \%$ \\
\hline 2015 & 1.037 .584 .453 .768 .26 & $5.65 \%$ \\
\hline 2016 & 607.740 .926 .745 .28 & $10.83 \%$ \\
\hline 2017 & 1.380 .601 .504 .519 & $2.67 \%$ \\
\hline 2018 & 1.537 .275 .105 .768 & $2.79 \%$ \\
\hline 2019 & 1.610 .370 .000 .000 & $4.20 \%$ \\
\hline
\end{tabular}

Source: Directorate General of Tax Balance, 2010-2019

Based on the data above, South Sumatra's capital expenditures in the last 10 years have experienced quite a fluctuating or unstable fluctuation in the value of the annual expenditure budget. This is because every year the need for capital expenditure for the province of South Sumatra changes according to the portion of its needs.

\subsection{Research Problem}

Based on the research background that has been stated previously, the problems in this study are:

Based on the research background that has been stated previously, the problems in this study are:

1. Does local tax affect the capital expenditure of the South Sumatra Provincial government for the 2010-2019 Period? 
2. Does the general allocation fund affect the 2010-2019 South Sumatra Provincial government capital Expenditure?

3. Does the special allocation Fund affect the 2010-2019 South Sumatra Provincial government capital expenditure?

4. Do regional taxes, general allocation funds, and special allocation funds affect the 2010-2019 South Sumatra Provincial government capital expenditures?

\subsection{Research Objectives}

The purpose of this research is to find out:

1. Analyzing the effect of regional tax on capital expenditure of the South Sumatra Provincial government for the 2010-2019 Period.

2. Analyzing the effect of the general allocation Fund on the capital expenditure of the South Sumatra Provincial government for the 2010-2019 period.

3. Analyzing the effect of the special allocation Fund on the capital expenditure of the South Sumatra Provincial government for the 2010-2019 period.

4. Analyzing the effect of regional taxes, general allocation funds and special allocation funds on capital expenditures of the South Sumatra Provincial government 2010-2019.

\section{Literature Review}

\subsection{Government Expenditure Theory}

Government spending theory refers to policies by the government, the government implements policies to buy goods and services needed in the regions, so that government spending will reflect the costs that must be incurred by the government in implementing its policies. The theory of government spending is divided into two parts, namely macro and micro.

\subsection{Local Tax}

Local taxes are mandatory contributions to regions owed by individuals or entities that are forced under the law without getting a direct imbalance and are used for regional needs for the greatest prosperity of the people (Mardiasmo, 2011:12; Setyanto, E., \& Handayani, R., 2020)

\subsection{General Allocation Fund}

According to Awan (2011: 19) "General allocation funds are a type of inter-government fund transfer that does not determine the specific contest program". Indraningrum (2011: 23) Identify several benefits of the central government providing aid funds in the form of block grants to local governments, namely:

1. To encourage the creation of justice between regions (geographical equity)

2. To increase accountability (increase accountability)

3. To improve a more advanced tax system. Local taxes tend to be less progressive, low taxes for low people

4. To increase the acceptability of local taxes. The central government subsidizes some local government spending to reduce the amount of local taxes. 


\subsection{Special Allocation Fund}

According to Halim (2014: 16) Special Allocation Funds are funds sourced from the APBN which are allocated to certain regions with the aim of helping to fund special activities which are regional affairs and in accordance with national priorities. The special allocation fund is used to close the gap in public services between regions by giving priority to the fields of education, health, infrastructure, marine and fisheries, agriculture, local government infrastructure, and the environment. If managed properly, this special allocation fund which is specifically used for the construction and rehabilitation of physical facilities and infrastructure can help reduce poverty and in general, can be used to develop the national economy.

\subsection{Capital Expenditure}

Government Accounting Standards (SAP) reveal that capital expenditures are expenditures made in the context of capital formation that is in nature to add fixed assets or inventory that provide benefits for more than one accounting period, including expenditures for maintenance costs that are maintaining or increasing the useful life, and increase capacity and asset quality. Capital Expenditure is a component of regional Expenditure contained in the structure of the Regional Revenue and Expenditure Budget (APBD) where Capital Expenditure is the APBD that can most influence development, especially the human development index (IPM).

According to Purwanto (2013: 9) theoretically, there are 3 (three) ways to obtain fixed assets, namely by building their own, exchanging them with other fixed assets, and buying. Siallagan (2016: 21) argues that expenditure can be categorized as capital expenditure if:

1. Expenditures result in the acquisition of fixed assets or other assets thus

2. The expenditure exceeds the minimum capitalization limit for fixed assets or others that have been determined by the regional government.

3. The acquisition of fixed assets is not intended to be sold.

\subsection{Research Hypothesis}

The hypotheses in this study are as follows:

H1: Local Taxes have a positive effect on the Capital Expenditure of the South Sumatra Provincial Government for the 2010-2019 period.

H2: The General Allocation Fund has a positive effect on the Capital Expenditure of the South Sumatra Provincial Government for the 2010-2019 period.

H3: The Special Allocation Fund has a positive effect on the Capital Expenditure of the South Sumatra Provincial Government for the 2010-2019 period.

H4: Regional Taxes, General Allocation Funds, and Special Allocation Funds jointly have a positive effect on the Capital Expenditure of the South Sumatra Provincial Government for the 2010-2019 period.

\section{Research Method}

\subsection{Data Type}

Based on the scope of the research, the selected research period is 2010 to 2019 so that the type of data used is quantitative data. According to Sugiyono (2017:23) quantitative data is data in the form of numbers, or quantitative data that is scored (scoring). 


\subsection{Data Collection Techniques}

The data collection technique used in this research is the documentation method. Documentation according to Sugiyono (2015: 329) is a method used to obtain data and information in the form of books, archives, documents, written numbers, and pictures in the form of reports and information that can support research.

\subsection{Population}

According to Sugiyono (2017:119) population is a generalization area consisting of objects and subjects that have certain qualities and characteristics determined by research to be studied and then drawn conclusions. The population in this study is the Regency/City of South Sumatra Province.

\subsection{Analysis Techniques}

The data analysis technique used in this research is multiple linear regression analysis. In multiple linear regression analysis, so that the regression equation is suitable for use or application, it must meet the classical assumption test so that the test results are unbiased and efficient (Best Linear Unbiased Estimator / BLUE). Classical assumption test includes normality test, multicollinearity test, heteroscedasticity test, and autocorrelation test (Supriyadi, 2014: 71). Normality test was not used in this study because this study used all research subjects (not using samples).

\section{Findings and Discussions}

This study utilized four data, namely local taxes, general allocation funds, special allocation funds and capital expenditures. This research was conducted using the classical assumption test which is a requirement that must be met based on Ordinary Lease Square (OLS) and to ensure that the regression model meets four components consisting of: normality test, multicollinearity test, autocorrelation test, and heteroscedasticity test. The use of data using SPSS v.22.0, the results obtained are as follows:

\subsection{Classic Assumption Test Result}

\subsubsection{Normality Test Results}

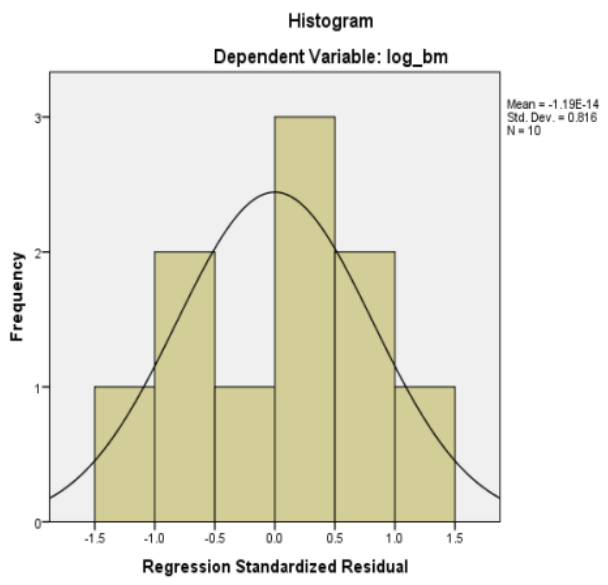

Figure 1. Normality Test Results - Histogram

Source: data processed with SPSS 22.0, 2020 
From the normality histogram graph display above, it can be concluded that the histogram shows a normal distribution pattern. The normal distribution will form a straight diagonal line, and the residual data plot will be compared with the diagonal line. If the distribution of residual data is normal, then the line that describes the actual data will follow the diagonal line.

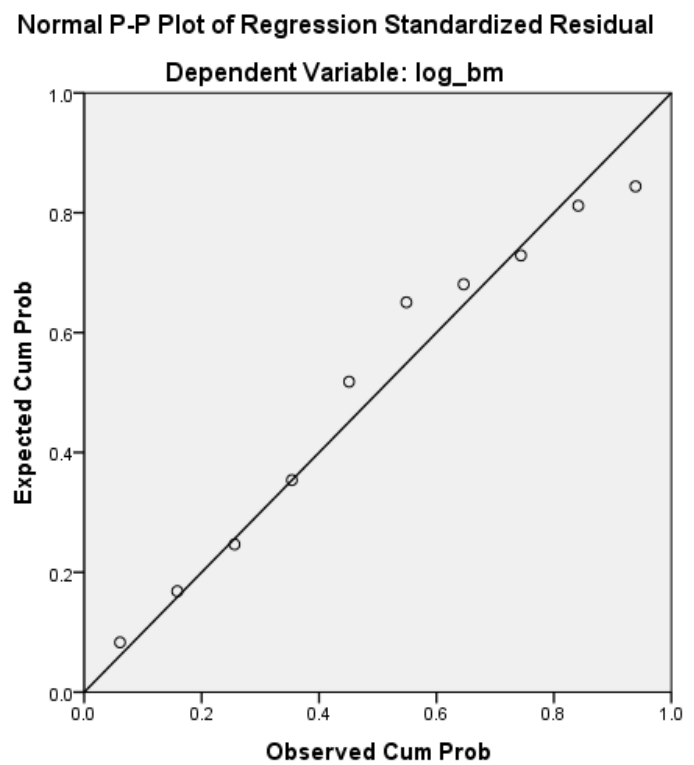

Figure 2. Normality-P-Plot . Test Results

Source: data processed with SPSS 22.0, 2020

In the normal probability graph above, it can be seen that the points spread close together around the diagonal line, and the spread follows the diagonal line. So this regression model meets the assumption of normality.

\subsubsection{Multicollinearity Test}

Table 2. Multicollinearity Test Results

\begin{tabular}{|l|c|c|}
\hline \multirow{2}{*}{ Variable } & \multicolumn{2}{c|}{ Collinearity Statistics } \\
\cline { 2 - 3 } & Tolerance & VIF \\
\hline Local tax & .908 & 1.101 \\
\hline General Allocation Fund & .877 & 1.141 \\
\hline Special Allocation Fund & .924 & 1.083 \\
\hline
\end{tabular}

Source: data processed with SPSS 22.0, 2020

Based on the multicollinearity test in this study, the local tax variable is 1.101 , the general allocation fund variable is 1.141 and the special allocation fund variable is $1.803>$ than 10 so that this research model does not have multicollinearity problems. 


\subsubsection{Autocorrelation Test}

To determine the presence or absence of autocorrelation can be seen with the value of the Durbin-Watson (D-W) test.

Table 3. Autocorrelation Test Results

Model Summary ${ }^{b}$

\begin{tabular}{|l|r|r|r|r|r|}
\hline Model & \multicolumn{1}{|c|}{$\mathrm{R}$} & R Square & \multicolumn{1}{c|}{$\begin{array}{c}\text { Adjusted R } \\
\text { Square }\end{array}$} & $\begin{array}{l}\text { Std. Error of the } \\
\text { Estimate }\end{array}$ & Durbin-Watson \\
\hline 1 & $.879^{\mathrm{a}}$ & .773 & .659 & .17702 & 1.051 \\
\hline
\end{tabular}

a. Predictors: (Constant), log_dak, $\log \_p d, \log \_$dau

b. Dependent Variable: log_bm

Source: data processed with SPSS 22.0, 2020

The result of this test is calculated DW $=1.051$ so that the Durbin Watson model in this study if the DW lies between -2 to +2 means that there is no autocorrelation (Santoso, 2015). So that this research model is free from autocorrelation problems because $2<\mathrm{DW}$ is 1,051 .

\subsubsection{Heteroscedasticity Test}

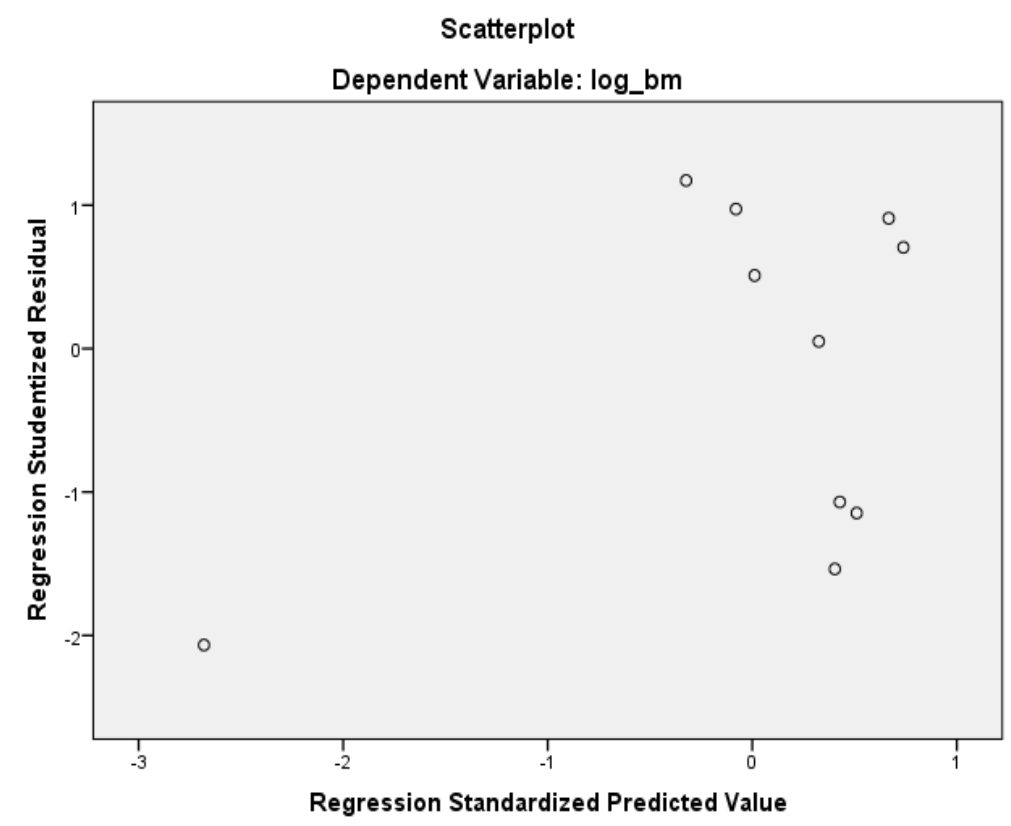

Figure 3. Heteroscedasticity-Scatterplot. Test Results

Source: data processed with SPSS 22.0, 2020

From the results of this study, it can be seen that the pattern of points is spread out and nothing is clear and the points are spread above and below zero on the $\mathrm{Y}$ axis, so there is no heteroscedasticity. Based on the picture above, it can be seen that the dots (plots) spread 
randomly and spread both above and below the number 0 . The pattern of scattering of dots (plots) is irregular and does not form a certain pattern. Therefore, it can be concluded that the regression model shows that the research data does not have heteroscedasticity problems.

\subsection{Multiple Regression Analysis}

Table 4. Summary of Multiple Linear Regression Test Results

\begin{tabular}{|c|c|c|c|c|c|c|}
\hline $\begin{array}{c}\text { Independent } \\
\text { Variable }\end{array}$ & $\begin{array}{l}\text { Regression } \\
\text { Coefficient }\end{array}$ & Ry (123) & $\mathrm{R}^{2} \mathrm{y}(1,2,3)$ & Sig & $F_{\text {count }}$ & Explanation \\
\hline Constant & 2.897 & \multirow{4}{*}{0,879} & \multirow{4}{*}{0,773} & \multirow{4}{*}{0,023} & \multirow{4}{*}{6,807} & \multirow{4}{*}{ Significant } \\
\hline LogPD & $-0,028$ & & & & & \\
\hline LogDAU & 0,927 & & & & & \\
\hline LogDAK & $-0,104$ & & & & & \\
\hline
\end{tabular}

Source: data processed with SPSS 22.0, 2020

From the results of multiple linear regression calculations in table 6 above, it can be seen the relationship between the independent variable and the dependent variable which can be formulated in the following formula:

$$
\begin{aligned}
& \operatorname{LogBm}=a+\log P D+\log D A U+\operatorname{LogDAK}+e \\
& \operatorname{LogBM}=2,897+\beta_{1} \log -0,028+\beta_{2} \log 0,927+\beta_{3} \log -0.104+e
\end{aligned}
$$

The equation can be interpreted as follows:

- The constant 2.897 states that if there are no independent variables that are considered constant $(\mathrm{X} 1=0, \mathrm{X} 2=0, \mathrm{X} 3=0)$, then the Capital Expenditure for each region is 2.897 .

- The Regional Tax Coefficient increases by -0.028 , meaning that if there is a change in PD by 1 percent, then Capital Expenditures will decrease by -0.028 or -2.8 percent. in the province of south sumatra

- The DAU General Allocation Fund increases by 0.927 , meaning that if there is a 1 percent change in DAU, it will increase Capital Expenditure by 0.927 or 92.7 percent.

- The coefficient of the Special Allocation Fund increased by -0.104 , meaning that if there was a 1 percent change in DAU, then Capital Expenditures would decrease by 0.104 or -10.4 percent. 


\subsection{Hypothesis Test Results}

\subsubsection{F Test}

Table 5. F Test Results

ANOVA $^{\mathrm{a}}$

\begin{tabular}{|rr|r|r|r|r|r|}
\hline \multicolumn{2}{|l|}{ Model } & Sum of Squares & Df & Mean Square & F & Sig. \\
\hline 1 & Regression & .640 & 3 & .213 & 6.807 & $.023^{\mathrm{b}}$ \\
& Residual & .188 & 6 & .031 & & \\
& Total & .828 & 9 & & & \\
\hline
\end{tabular}

Source: data processed with SPSS 22.0, 2020

Based on the $\mathrm{f}$ test, the Prob value (F-Statistic) is 0.023 smaller than the critical F (F Table) at $\mathrm{a}=5 \%, \mathrm{df}=10-4=6$, which is 4.76 , which means that all independent variables in the model have a significant effect. real to capital expenditures. The significance of the third independent variable is also indicated by the probability value of $\mathrm{f}=0.023<0.05$ (ie the value of $5 \%$ ).

\subsection{2. $t$ - Test}

Table 6. t-Test Results

\begin{tabular}{|c|c|c|c|c|c|c|}
\hline \multirow{2}{*}{\multicolumn{2}{|c|}{ Model }} & \multicolumn{2}{|c|}{ Unstandardized Coefficients } & \multirow{2}{*}{$\begin{array}{c}\begin{array}{c}\text { Standardized } \\
\text { Coefficients }\end{array} \\
\text { Beta }\end{array}$} & \multirow[b]{2}{*}{$\mathrm{T}$} & \multirow[b]{2}{*}{ Sig. } \\
\hline & & B & Std. Error & & & \\
\hline \multirow[t]{4}{*}{1} & (Constant) & 2.897 & 4.873 & & .594 & .574 \\
\hline & log_pd & -.028 & .149 & -.039 & -.191 & .855 \\
\hline & $\log _{\text {dou }}$ & .927 & .218 & .884 & 4.255 & .005 \\
\hline & log_dak & -.104 & .077 & -.273 & -1.350 & .226 \\
\hline
\end{tabular}

Source: data processed with SPSS 22.0, 2020

From the results of table 5 it can be concluded that the t-statistical value on the local tax variable is -0.191 from the probability that the PD is 0.855 which indicates it is greater than the critical value so that $0.855>0.05$ which means that the local tax variable in this study has no significant and negative effect on capital expenditure.

Then the t-statistic value on the general allocation fund variable is 4.255 from the probability that the DAU is 0.005 which indicates it is smaller than the critical value so $0.005<0.05$, which means the general allocation fund variable in this study has a significant and positive 
effect on capital expenditure.

Meanwhile, the t-statistic value on the special allocation fund variable is -1350 from the probability that DAK is 0.026 which indicates it is greater than the critical value so $0.226>$ 0.05 which means that the special allocation fund variable in this study has no significant and negative effect on capital expenditures. .

\subsection{Coefficient of Determination}

Table 7. Results of the Coefficient of Determination

\begin{tabular}{|l|r|r|r|r|}
\hline Model & $\mathrm{R}$ & \multicolumn{1}{|c|}{ R Square } & Adjusted R Square & \multicolumn{1}{c|}{$\begin{array}{c}\text { Std. Error of the } \\
\text { Estimate }\end{array}$} \\
\hline 1 & $.879^{\mathrm{a}}$ & .773 & .659 & .17702 \\
\hline
\end{tabular}

Source: data processed with SPSS 22.0, 2020

From the results of data processing using SPSS, the coefficient of determination or R2 value of 0.773 means that the independent variables, namely local taxes, general allocation funds, and special allocation funds are able to explain their effect on the dependent variable of 77.30 percent while 22.70 percent is influenced by the variable other outside the model.

\section{Conclusions and Suggestions}

\subsection{Conclusions}

From the results of research and discussion in the previous chapter, the following conclusions can be drawn:

1. Regional Taxes have a negative and insignificant effect on Capital Expenditures in the South Sumatra Provincial Government for the 2010-2019 period. This is indicated by the t-statistic value on the Regional Tax variable of -0.191 from the probability that the local tax is 0.855 which indicates it is greater than the critical value so that $0.855>0.05$. The local tax variable has a negative and insignificant effect, this is because the high and low local taxes levied by the local government to the public are not in line with the growth of capital expenditures which tend to be determined by the needs of each region of South Sumatra Province.

2. The General Allocation Fund has a positive and significant effect on Capital Expenditures in the Provincial Government of South Sumatra for the 2010-2019 period. This is indicated by the t-statistical value of the general allocation fund variable of 4.225 from the probability of 0.05 which indicates that it is smaller than the critical value so that $0.005<0.05$. The general allocation fund variable has a positive and significant effect, this is because the use of the general allocation fund is for equitable distribution of regional finances in the context of providing basic services to the community. So that the higher the general allocation fund, the capital expenditure will increase.

3. The Special Allocation Fund has a negative and insignificant effect on capital expenditure in the South Sumatra Provincial government for the 2010-2019 period. This is indicated by the t-statistic value on the special allocation fund variable of -0.104 from the probability of DAK of 0.026 which indicates that it is greater than the critical value so that $0.026>0.05$. The variable of special allocation funds has a negative and insignificant 
effect because the percentage of special allocation funds is still low, only $1.34 \%$, thus causing the increase in special allocation funds that has not been followed by capital expenditures for the province of South Sumatra.

4. Regional Taxes, General Allocation Funds and Special Allocation Funds affect the Capital Expenditures of the South Sumatra Provincial Government for the 2010-2019 period. This is shown in the coefficient of determination or R2 obtained by 0.773 which means that the independent variable is able to explain its effect on the dependent variable of $77.30 \%$ while $22.70 \%$ is influenced by variables outside the model.

\subsection{Conclusions}

Based on the conclusions of the research, some suggestions are given, namely:

1. For the regional government of South Sumatra Province to further explore the potential of regional taxes by optimizing regional potentials because when regional taxes increase, it will increase the opportunities for the region to be able to meet the needs of the community from the income that can be obtained and regulate population mobility evenly so that the needs of the population can be fulfilled well with more effective government programs such as transmigration, urbanization, and others.

2. For future researchers to expand and multiply the sample as well as extend the observation period and add more variables that affect capital expenditures such as variables of Economic Growth, Population Density, Area, Regional Original Income, Regional Levies, Revenue Sharing Funds, and others -Other Legitimate Regional Income.

3. Local governments are also expected to be able to optimize the potentials that can increase the fiscal space for capital expenditure budgets such as effectively and efficiently utilizing regional resources, seeing regional potentials that can be utilized to be able to advance the region and enlarge the space for increased regional income. every year and better organize the allocation of capital expenditures so that they are channeled properly according to the needs of the region so that a good balance will be created between economic factors and capital expenditures that can increase regional economic growth on a macro basis.

\section{Reference}

Awaniz, B. N. (2011). Pengaruh Dana Alokasi Umum (DAU) dan Pendapatan Asli Daerah (PAD) Terhadap Belanja Daerah di Eks Karesidenan Pekalongan (Doctoral dissertation, Universitas Negeri Semarang).

Darise, N. (2009). Pengelolaan Keuangan Daerah Edisi Kedua. Penerbit PT. Indeks. Jakarta.

Halim, A. (2014). Manajemen Keuangan Sektor Publik: Problematika Penerimaan dan Pengeluaran Pemerintah. Jakarta: Salemba Empat.

Indonesia, R. (2019).Undang-Undang Republik Indonesia Nomor 20 Tahun 2019. Anggaran Pendapatan dan Belanja Negara. Jakarta (ID): RI.

Indonesia, R. (2004). Undang-Undang Republik Indonesia Nomor 32 Tahun 2004 Tentang Pemerintahan Daerah. Jakarta (ID): RI.

Indraningrum T. 2011. Pengaruh Pendapatan Asli Daerah (PAD) dan Dana Alokasi Umum (DAU) terhadap Belanja Langsung (Studi pada Pemerintah Daerah Kabupaten/Kota di 
Provinsi Jawa Tengah). Skripsi (dipublikasikan). Fakultas Ekonomika dan Bisnis, Universitas Diponegoro.

Mardiasmo. (2012). Perpajakan. Yogyakarta: CV. Andi Offiset.

Purwanto, E.A. \& Sulistyastuti, D.R. (2011). Metode Penelitian Kuantitatif UntukAdministrasi Publik Dan Masalah-masalah Sosial. Yogyakarta: Penerbit Gava Media.

Setyanto, E., \& Handayani, R. (2020). Pemanfaatan Teknologi Informasi dan Peningkatan Aksesibilitas Usaha Mikro, Kecil, dan Menengah (UMKM) dalam Community Based Tourism terhadap Penerimaan Pajak Daerah. Jurnal Ilmiah Ekonomi Global Masa Kini, 11(2), 66-70.

Siallagan, T. (2016). Analisis Flypaper Effect Pada Dana AlokasiUmum (Dau) Dan Pendapatan Asli Daerah (PAD)Terhadap Belanja Modal Pada Kabupaten/KotaDi Provinsi Sumatera Utara Tahun 2010-2013. (Skripsi, Universitas Sumatera Utara. Medan)

Sugiyono. (2015). Metode Penelitian Kombinasi (Mix Methods). Bandung: Alfabeta.

Sugiyono. (2017). Metode Penelitian Pendidikan Pendekatan Kuantitatif, Kualitatif, dan $R \& D$. Bandung: Alfabeta.

Supriyadi, E. (2014). SPSS+Amos Statistik Data Analysis. Jakarta: Penerbit IN MEDIA. 